\title{
CLINICAL STUDIES ON OLFACTORY DISTURBANCE WITH THE ADRENOCORTICAL HORMONE NOSE-DROPS
}

YOSHIKO FUKUSHIMA, M.D.

Department of Oto-Rhino-Laryngology, School of Medicine, Showa University, Tokyo

(Director: M. Okamoto, M.D.)

Recently the treatment of the olfactory disturbance has been investigated in many institutions extensively. However, the fruits of these studies were still far from perfect. In this study the treatment of the disturbance of the olfactory epithelium was investigated, because etiology of the olfactory disturbance was considered mostly as the abnormal change of the olfactory epithelium caused by nasal diseases (sinusitis, allergic or hypertrophic rhinitis etc).

The results of treatment 1376 outpatients visiting the olfactory clinic of the Department of Otorhinolaryngology at Showa University were presented as follows:

1) 1376 patients were divided into 4 types, respiratory olfactory disturbance, epithelial olfactory disturbance, combined olfactory disturbance and central olfactory disturbance, and $96 \%$ of them were of epithelial and combined type.

2) In treatments 2 or 3 drops of $0.1 \% \beta$-methasone or $0.1 \%$ dexamethasone nose drop were applied on olfactory mucosa in the patients, head down position as basic treatment.

3) As the result of treatment, $37.5 \%$ of respiratory type, $68.6 \%$ of epithelial type and $75.7 \%$ of combined type were recovered completly or remarkably but none of the central type recovered.

4) Side effects were studies after the administration of $5 \mathrm{ml} /$ week of $0.1 \%$ dexamethasone or $0.1 \% \beta$-methasone solution for 16 weeks, and the results of rapid ACTH test and the other adrenocortical function studies were normal.

By this treatment, nearly $70 \%$ of the patients visiting our clinic were recovered completly or satisfactorily.

Therefore nose-drops of adrenocortical hormone were considered very useful for the treatment of olfactory disturbances.

A $81-0036-32525$

\section{唤覚障害の治 療 法}

\section{一一特に副腎皮質ホルモン点鼻療法に関する臨休的研究——}

\section{昭和大学医学部耳敫咽喉科学教空（主任：凧本途也教授）}

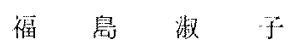

\section{I 緒 言}

人間の感覚には五感がある。言うまでもなく，視覚，

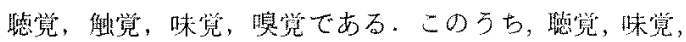

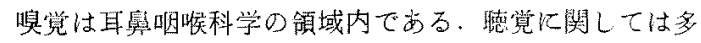

くの研究が厽り，臨床的にも，診断，治療が充分行わ れてきた。しかし、こ机に反し，咱党汇関しての臨床は， ごく最近学で碓立された検查法すらなく，その障害部位 の診断も漠然としたむのであった。このため治療法もピ 
タミン戍などの投与で経過をみるという方法しかなかっ

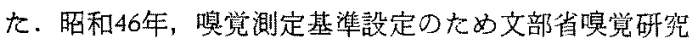
班加編成され，之の方面の研究加始められた，昭和大学

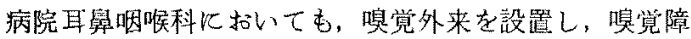
害者を專門に診察するようになった，交の結果現在悉で

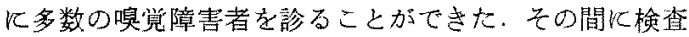

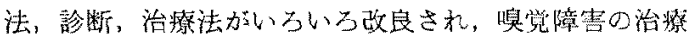

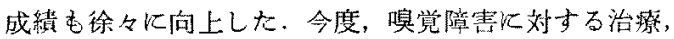
特に，副繁皮質ホルモン点鼻療法について集計し，検討 したので報告する。

\section{II 研究方法}

(1) 対 象

昭和47年より昭和51年までの5年間に昭和大学病院耳

表 1 昭和 $47 \sim$ 略和51年の炤和大学耳悬咽喉科

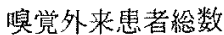

\begin{tabular}{|c|c|c|c|}
\hline & 男性 & 女 & 黄市 \\
\hline 炤和 47 年 & 244 名 & 372 名 & 596 名 \\
\hline 昭 和 48 年 & $71 " 1$ & $114 / 1$ & $185 "$ \\
\hline 昭和 48 年 & $55 "$ & $74 \prime \prime$ & 129 \\
\hline 昭和 50 年 & $131 "$ & $193 "$ & $324 \prime$ \\
\hline 时利 51 年 & $59 \prime \prime$ & $83 \prime$ & $142 "$ \\
\hline 苦 & $\begin{array}{c}540 " \prime \\
(39.2 \%)\end{array}$ & $\begin{array}{c}836 \% \\
(60.8 \%)\end{array}$ & 1.376 名 \\
\hline
\end{tabular}

舅咽喉科咽览外来を訪ずれた嗅觉障害を主侶とする患者 1,375 例を刘象とした（表1）。

(2) 検查方法

第76回日本耳舅咽喉科学会総会研修会にて，淺賀加咱 党検查法と題して满演した力法に基すく ${ }^{23}$ 。をの大略を 述ヘると
a 問 㟝
b 前舆鏡検查

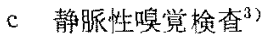
d レントゲン撮影()

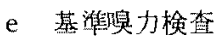
f 針状硬性鏡検盖 ${ }^{5}$
g 直接送b込み法

である。

(3) 彰 断

前記諸検查の結果を総合的に判定して障害部位の診断 を行った(表 2)。障传部位別の類度は，呼吸性，中枢性 障害は，ごく少数で混合性，舆数膜性障害が圧倒的に多 く，雨者を合わ世ると全体の96.1\%であった（表3）.

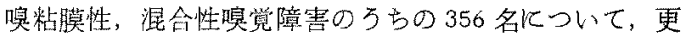
飞針状硬性鏡検查を行い, 腫脹型，分泌型，不变型，菱 縮型，肥厚型の5型飞分類した 脹型で最も多く，(56.5\%)，不变型がこれにつつき98例 $(27.5 \%)$ ，分佖型 26 例 (7.3\%) と腿厚型23例 (6.5\%)

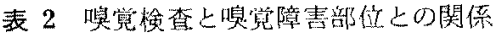

\begin{tabular}{|c|c|c|c|c|c|}
\hline 障 害 部 & 位 & 基準嗅力検查 & 静脉性秵觉検查 & 釬，状硬性镜検查 & 直接送り込双法 \\
\hline 中枢性筃覚陪 & 害 & 不定 & 定 & 買常所見なし？ & 不 \\
\hline $\begin{array}{c}\text { 䙼粘膜性懙覚障害 } \\
\text { (喂) }\end{array}$ & 泥嗔 & 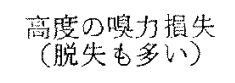 & 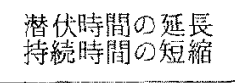 & 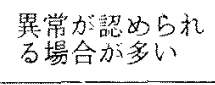 & 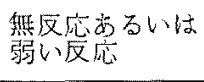 \\
\hline 呼吸性嗅党障 & 性害 & 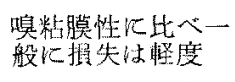 & 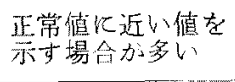 & 翼常所見なし & 正常に反応あり \\
\hline
\end{tabular}

表 3 嗅覚障害部位别・嗅粈膜所見别頻度

\begin{tabular}{|c|c|c|c|}
\hline 咀觉障害部位 & 症 & 例 数 & \\
\hline 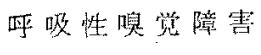 & & $(1.8 \%)$ & 㘰状硐性 \\
\hline 淈合性嗅管㜔慧 & 659 & $(47.9 \%)$ & 検查で分類 \\
\hline 唤粘膜性鮕觉障害 & 663 & $(48.2 \%)$ & \\
\hline 中枢性邉覚障害 & 28 & $(2.0 \%)$ & \\
\hline 合 & 1,376 & $(100.0 \%)$ & \\
\hline
\end{tabular}

\begin{tabular}{|c|c|c|c|}
\hline \multicolumn{3}{|c|}{ 嗄粘膜所見別 } & 掟 例 数 \\
\hline 腫 & 龂 & 型 & $201(56.5 \%)$ \\
\hline 分 & 㐬 & 型 & $26(7.3 \%)$ \\
\hline 不 & 烌 & 型 & $98(27.5 \%)$ \\
\hline 把 & 厚 & 型 & $23(6.5 \%)$ \\
\hline 萎 & 維 & 型 & $8(2.2 \%)$ \\
\hline & & $\$$ & $356(100.0 \%)$ \\
\hline
\end{tabular}




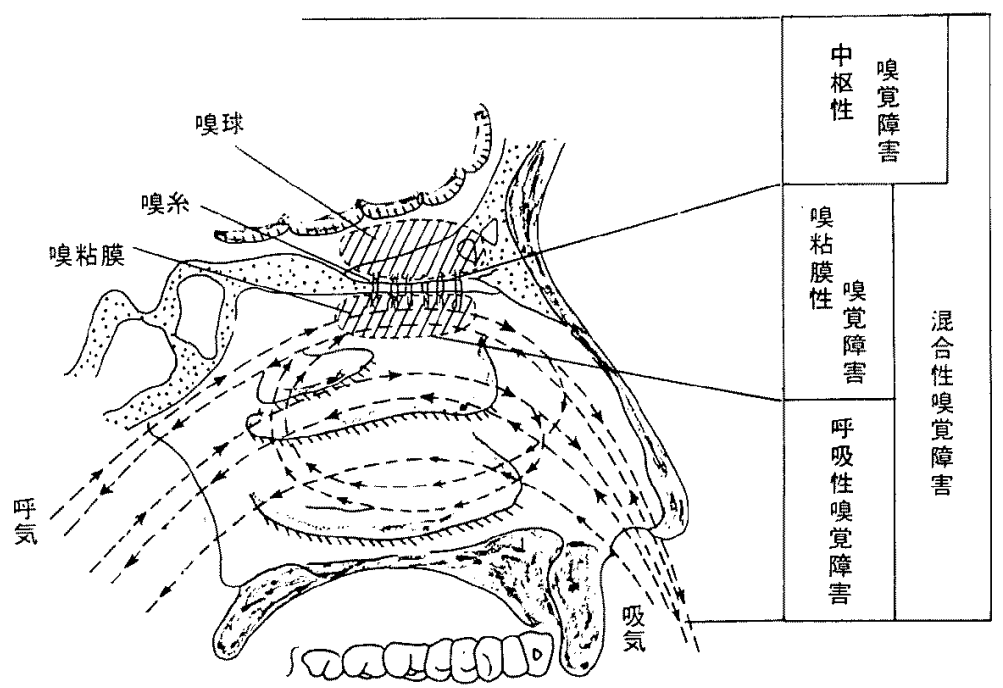

図 1 唤觉㖏㫪部仿别分類

は、ほほ同婆て，萎縮型 8 例 (2.2\%)は非常に少なかっ ז.

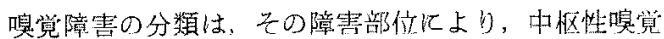

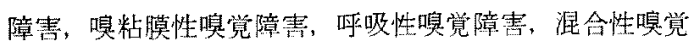
障害とした（図1).

\section{(4) 治爒法}

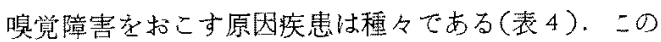
原因疾患の治療が唤覚障害治療の基礎であるが、ここで

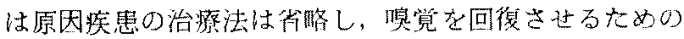
治潦法を述へる。

この治療法の原則は，副腎皮質ホルモン液を㬎琹頭位

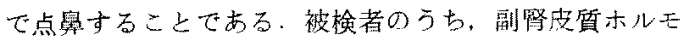
ン投与禁忌例を除く全例炕点眼, 点耳液として発壳され ている $0.1 \%$ \%゙キサメサゾン又は，ベタメサゾンの点

表 4 嗅觉障害の原因别統棓!

\begin{tabular}{|c|c|c|}
\hline 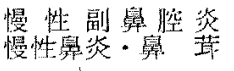 & 578 例 & $42.0 \%$ \\
\hline 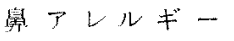 & 153 例 & $11.2 \%$ \\
\hline カ ゼ の 後 & 274 例 & $19.9 \%$ \\
\hline 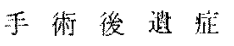 & 46 例 & $3.3 \%$ \\
\hline 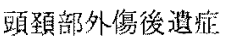 & 43 例 & $3.1 \%$ \\
\hline$\infty$ & 2 例 & $0.1 \%$ \\
\hline 明 & 280 例 & $20.4 \%$ \\
\hline 䛎 & $\mathrm{I}, 376$ 例 & $100 \%$ \\
\hline
\end{tabular}

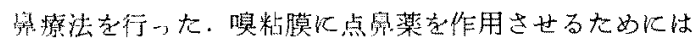

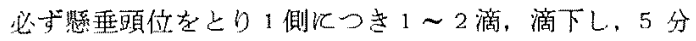
間，そのままの姿勢在保つ.これを朝，眖，2回行う. 市眅の $5 \mathrm{ml}$ 入り 1 週間に1 本の割で使用する(図2).

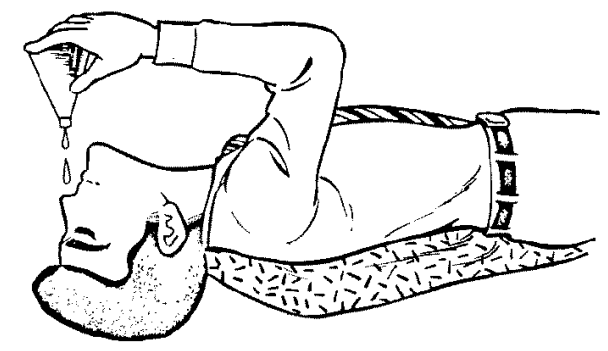

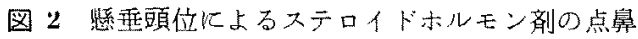
(要点)

○完全な影重頭位をとらせる。

○一回の点舅は 1 侧につさ $2 \sim 3$ 滴ずつ, 両侧に 行店亏。

○点舅㣪 5 分間はそのま末览垂頭位を保つ.

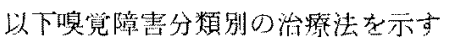

(A) 呼吸性喚觉障害

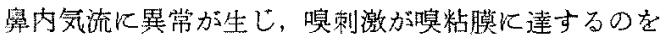
障害しているあので，この障害者に効しては，呼吸性の

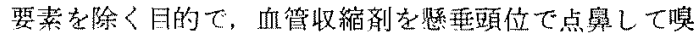
裂部を閶大した後，副腎皮質ホルモン液の点鼠を施行し 


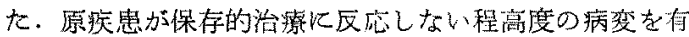
するものに対しては，手術療法を行つた，しかし，乎術 時には舅粘膜の損倠を最小限にとどめるよう注意しなけ

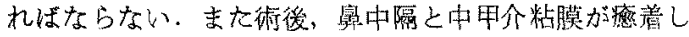
噢党障害を招こすこともあるので注意を要する。

(B) 嚊粘膜性嗅筧障慧

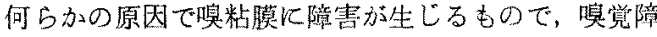
害のうちで，最も高度の咱力賣失をともなう。呼吸性障 害がないため手術箱法の対象上ならず，薬物療法が中心

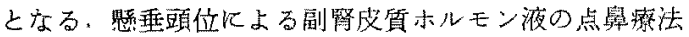
を最初行い，回復傾向のないもの烛，各種血流改墨 剂，針治療在併用した。

(C) 混合性鮕筧障表

治療法は，(A)，(B)，に準ずるが，姃例によっては， 消炎醉素剂，抗七スタ:ン剂，炶膜正常化剂などを併用 した.

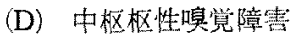

副㹂皮質ホルモン点䁷潦法に併用して，各程值流改善 剂，ATP製郕占などを投与した。
（5）治潦效果の判定基㴬

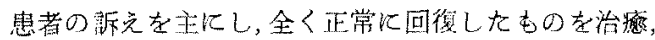
生活上嗅觉が役方つ程度に回復したもの，例えば，力゙大， コゲ，腐敗臭がかかるものを軽怯，来院洔とかわらない まのを無効とした。

(6) 副作用検重

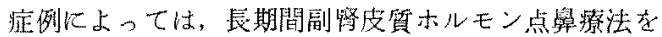
揓行するので，その剧作用を考虑し，副篮皮質機能検查:

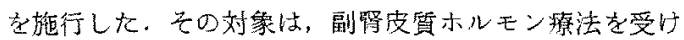

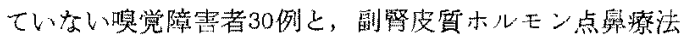
走1力月〜36力月，連続施行しているあの36例であ る。检查法 $\left.{ }^{78}\right)$ は，迅速副腎皮質譏能検查 (Rapid ACTH test）である

III 症例

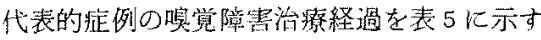

\section{V 研究成績}

(1) 治療成結

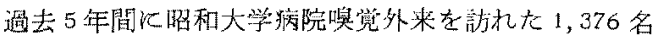

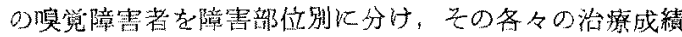

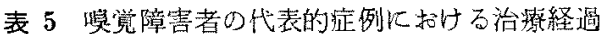

\begin{tabular}{|c|c|c|c|c|c|c|}
\hline 症例 & I & II & III & N & V & Y \\
\hline 年 齡 - 性 & $52 む$ & 468 & 189 & 279 & 35 우 & $54 \delta$ \\
\hline 主訴 & 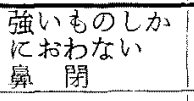 & 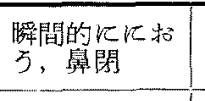 & $\begin{array}{l}\text { 生ま杣つきに } \\
\text { 括いを知占な } \\
\text { い }\end{array}$ & $\begin{array}{l}\text { 3兵前から徐 } \\
\text { 々に括わな } \\
\text { くなった }\end{array}$ & $\begin{array}{l}\text { 風邪のおと } \\
\text { に拉ねくな } \\
\text { った }\end{array}$ & $\begin{array}{l}\text { 後頭部打撲捘 } \\
\text { 常にコゲ累が } \\
\text { さる }\end{array}$ \\
\hline 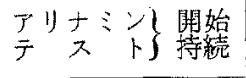 & $\begin{array}{l}10 \text { 秒 } \\
1 \text { 分 } 40 \text { 秒 }\end{array}$ & $\begin{array}{l}21 \text { 秒 } \\
48 \text { 秒 }\end{array}$ & 反応 $(-)$ & 反応 $(-)$ & 反心 $(-)$ & 反底 $(-)$ \\
\hline 前 睨 鏡 検 查 & 嶨荤充㶓 & 甲介腫脹 & 粘膜荅白 & 翼中隔刑曲 & 正 常 & 正 常 \\
\hline レンド篹裂部断曆 & $\begin{array}{c}\text { 上颚洞陰影 }(+) \\
\text { 開 }\end{array}$ & $\begin{array}{l}\text { 上顎洞险影 }(+) \\
\quad \text { 閂 }\end{array}$ & 正 閽 & $\begin{array}{c}\text { 箭骨洞䧔影 }(+) \\
\text { 閉 }\end{array}$ & 正常 & E 眮 $^{\text {常 }}$ \\
\hline 針状硬性 鏡所見 & 不变型 & 湩脹型 & 分闷型 & 肥厚型 & 菱縮型 & 不変型 \\
\hline 画接送り込外法 & 正常反応 & 反虑 (一) & 反応 $(-)$ & 反応 $(-)$ & 反笖 $(-)$ & 反岕 $(-)$ \\
\hline 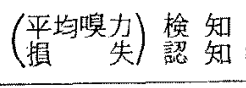 & $\begin{array}{c}2 \\
2.6\end{array}$ & $\begin{array}{l}5.8 \\
5.8 \\
\end{array}$ & $\begin{array}{l}0.4 \\
5.8\end{array}$ & $\begin{array}{l}0.4 \\
5.8\end{array}$ & $\begin{array}{l}5.8 \\
5.8 \\
\end{array}$ & $\begin{array}{l}5.8 \\
5.8\end{array}$ \\
\hline 䛦 & 哷吸性 & 混合性 & 咀粘腅性 & 混合性: & 嗅粘膜性 & 中枢性 \\
\hline 治 療 法 & 鲎葉切除 & $\begin{array}{l}\text { フールタイ ジン } \\
\text { リンデロン点㔍 }\end{array}$ & $\begin{array}{l}\text { 1)ンデロン点 } \\
\text { 舅 }\end{array}$ & 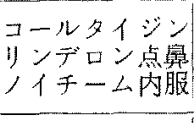 & 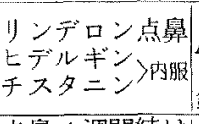 & 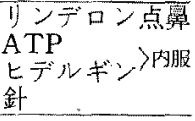 \\
\hline 治 療 期 間 & 術後回復 & $\begin{array}{l}4 \text { 日目頃より } \\
\text { 回復 }\end{array}$ & 羾日上り回復 & $\begin{array}{l}20 \text { 日目形より } \\
\text { 回復 }\end{array}$ & 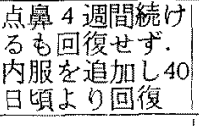 & $\begin{array}{l}\text { 12力月浩镣 } \\
\text { 変化なし }\end{array}$ \\
\hline 治 療 成 績 & 完 治 & 完治 & 完 治 & 柽 快 & 輟 快 & 不 変 \\
\hline
\end{tabular}


垡 6 噺喾障害部位则治寮成績

\begin{tabular}{|c|c|c|c|c|c|c|}
\hline & \multirow{2}{*}{ 症 例 数 } & \multicolumn{2}{|c|}{ 治 } & 結 & 果 & \multirow[b]{2}{*}{ 不 明 } \\
\hline & & 治 & 柽快 & 変 & 合 & \\
\hline 呼吸性鮕喾障害 & 26 & 15 & 6 & 3 & 24 & 2 \\
\hline 混合性嬹党障害 & 659 & 181 & 245 & 137 & 563 & 96 \\
\hline 嗅粘膜性嗔覚障害 & 663 & 116 & 251 & 168 & 535 & 128 \\
\hline 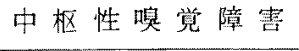 & 28 & 0 & 0 & 19 & 19 & 9 \\
\hline 合 & 1,376 & $\begin{array}{c}312 \\
(27.3 \%)\end{array}$ & $\begin{array}{c}502 \\
(44.0 \%)\end{array}$ & $\begin{array}{c}327 \\
(28.7 \%)\end{array}$ & $\begin{array}{c}1,141 \\
(100 \%)\end{array}$ & 235 \\
\hline
\end{tabular}

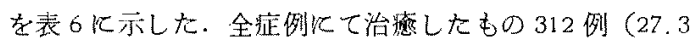
$\%$ ，軽快した6の 502 例 (44.0\%) で治瘵効果のあっ たものは814例 (71.3\%) であった。

障害部位别でみると治瘜率は呼吸性障害がもっとも高

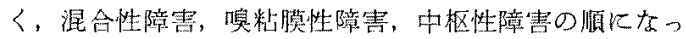
た。軽块率では嗔粘膜性障害がもっとも高く，韲合性障 害, 呼吸性障害, 中枢性障害の順であった。これらを総 合すると治潦により効果を認めた秃のは，呼吸性障害が 屯っ上委高く $87.5 \%$ で，混侖性障害 $(75.7 \%)$ ，舆粘膜性 障害 $(68.6 \%)$ の㮌となり，中枢性障害では1例我効果 を認めなかっ。

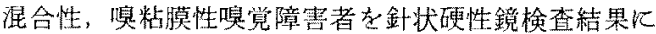

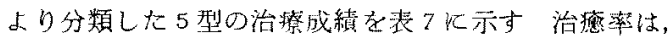
分泌型，腫脹型が高く，萎縮型，不变型，肥厚型の腼と なった。整快率は，菱縮型，腫脤型，分泌型が高く，不 变型、肥厚型となった。これを総合すると治燎効棸のお

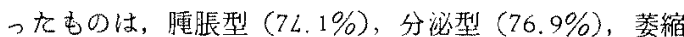
型 $(75.0 \%)$ が高く, 次いで不变型 $(62.3 \%)$, 肥桪型 (52.2\%)の順となった。

(3) 副作用検查結果

判定基準9 は ACTH 投与前の血中 $11-\mathrm{OHCS}$ 值が

变 7 針状硬性鏡検查によ万病型别治滰成綪

\begin{tabular}{|c|c|c|c|c|c|}
\hline 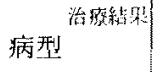 & 治 痽 & 塵 快 & 不 变 & 合 嚆 & 不明 \\
\hline 腫 脹 型 & 63 & 92 & 46 & 201 & 33 \\
\hline 分泌型 & 9 & 11 & 6 & 26 & 3 \\
\hline 不荻型 & 22 & 39 & 37 & 98 & 19 \\
\hline 肥 厚 型 & 4 & 8 & 11 & 23 & 7 \\
\hline 菱 縮 型 & 2 & 4 & 2 & 8 & 0 \\
\hline 會 計 & $\begin{array}{c}100 \\
(28,1 \%)\end{array}$ & $\begin{array}{c}154 \\
(43.3 \%)\end{array}$ & $\left(\begin{array}{c}102 \\
(28.6 \%)\end{array}\right.$ & $\begin{array}{c}356 \\
(100 \%)\end{array}$ & 42 \\
\hline
\end{tabular}

$10 \mu \mathrm{g} / 100 \mathrm{~m} l$ 末満の場合は, ACTH投与後の 11-OHCS 值が 2 倍以上, $10 \mu \mathrm{g} / 100 \mathrm{~m} l$ 以上のときは, 約 1.5 倍以 上に增加しているものを正常とした。

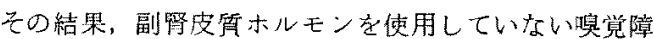

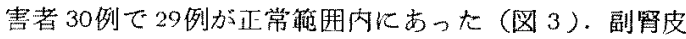
質ホルモン点舅整法老行った嗅筧障兲者36例で正常籍 国内30例，副珡皮質機能低下上判定されたもの6例があ 。た（図 4)。乙れ点鼻使用期間別にみると，点鼻療法

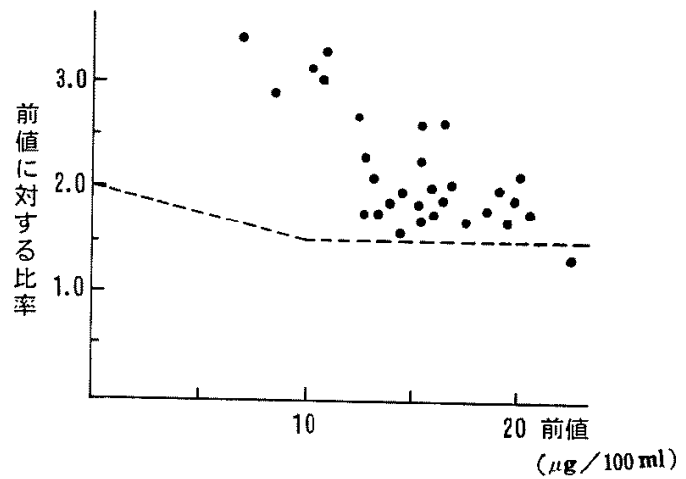

図 3 副腎皮管ホルモン剂使用前の过速 副腎皮質機能検查結果

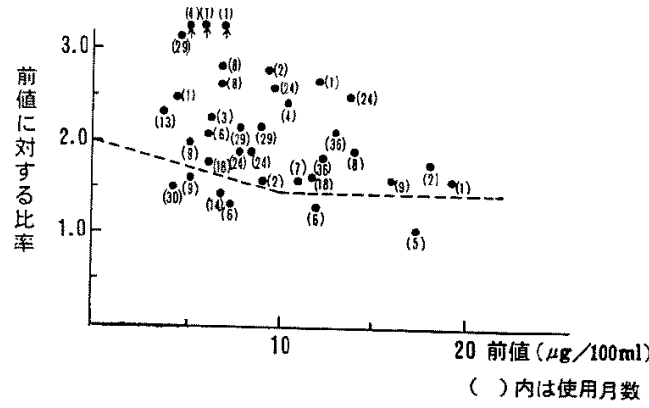

图4副等皮質ホルモン削使用後の迁速 副繁皮質機能検查結果 


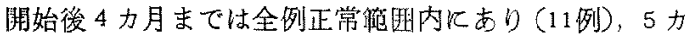
月 1 例, 6 力月 2 例, 9 力月 1 例, 14 力月 1 例， 30 力月 1 例，計 6 例が皮質機能低下と判定された，しかし，36 个月 2 例，29力月 3 例，その他 14 例上使用期間が，加少 り長い屯のでも正常範围内にあった（表8）.

表 8 副掔皮質機能検査成績 (点滰群)

\begin{tabular}{c|c|c|c}
\hline 使用月数 & 人 数 & 正常 & 譏能低下 \\
\hline 1 力月 & 5 & 5 & 0 \\
2 & 3 & 3 & 0 \\
3 & 1 & 1 & 0 \\
4 & 2 & 2 & 0 \\
5 & 1 & 0 & 1 \\
6 & 3 & 1 & 2 \\
7 & 1 & 1 & 0 \\
8 & 3 & 3 & 0 \\
9 & 3 & 2 & 1 \\
13 & 1 & 1 & 0 \\
14 & 1 & 0 & 1 \\
18 & 2 & 2 & 0 \\
24 & 4 & 4 & 0 \\
29 & 3 & 3 & 0 \\
30 & 1 & 0 & 1 \\
36 & 2 & 2 & 0 \\
計 & 36 & 30 & 6 \\
\hline
\end{tabular}

この検查を行う場合には，検植前24眭間は，副㹂皮貿

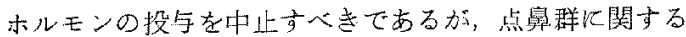
険查では，副紫皮質ホルモンの点鼻を綕けながら行った ためフィードバック機構が作用して拈り，中抑制され

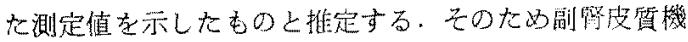
能低下と判定されたものがいる可能性もある。

\section{$y$ 考按}

嗅賞障害は人体の感賞障害のなかです，その存在は霜

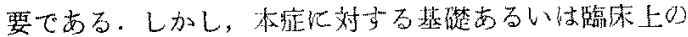

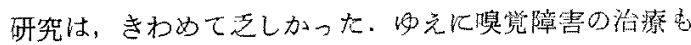

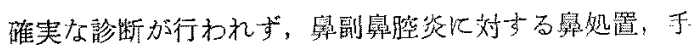
術以外は，ほ上んと有効な治療法がなかったといっても 過言で蛙ない。

嗅覚障害を治療するにあたり，重要なことは，鮕覚の

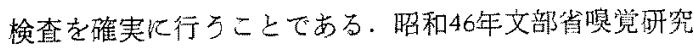

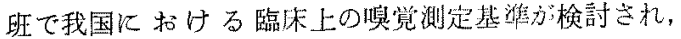

T\&Tオルファタトメーターが作整され全国的に統一さ れた検查法が礁立されるようになった。この検概法の閒

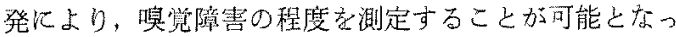
t.

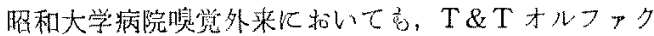
トメーターによる鮕力检查施行しているが，突觉障害

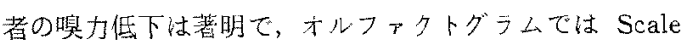

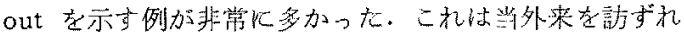

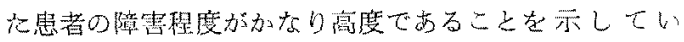

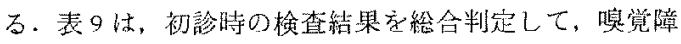

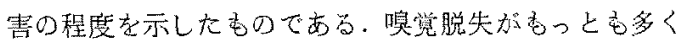
全体の80\%であり，减退之脱失を反復しているすのを含 わると86\%をしわていた。

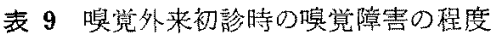

\begin{tabular}{|c|c|c|}
\hline 異 & 無 & 32 例 $(2.3 \%)$ \\
\hline 脱 & 失 & $1,101 "(80.0 \%)$ \\
\hline 減 & 張 & $131 "(9.6 \%)$ \\
\hline & 失 & $83 "(6.0 \%)$ \\
\hline 琵 & 舆 & $29 \|(2.1 \%)$ \\
\hline \multicolumn{2}{|c|}{ 計 } & 1,376 例 \\
\hline
\end{tabular}

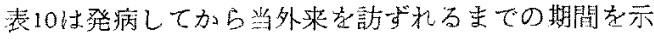
したもので，発病㣪 2 年以上経過しているものが 670 例 でもっとも多い，このなか比は，他医で治療していた症 例が，かなり含まれている。

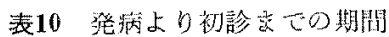

\begin{tabular}{|c|c|}
\hline 1 週閻以内 & 13 列 \\
\hline$\sim 1$ 力月以内 & $60 "$ \\
\hline$\sim 3$ 力月以内 & $87 "$ \\
\hline$\sim 6 力$ 月以内 & $111 "$ \\
\hline ～ 1 年 以内 & $145 \quad \prime$ \\
\hline ～ 2 年以内 & $271 "$ \\
\hline 2 年以上 & $670 "$ \\
\hline 不明 & $18 "$ \\
\hline 棓 & 1,376 例 \\
\hline
\end{tabular}

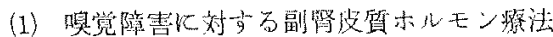

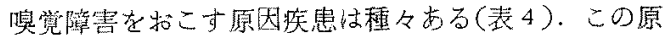

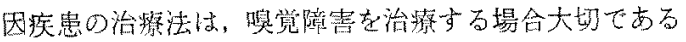

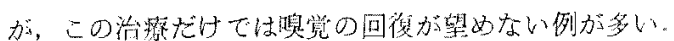

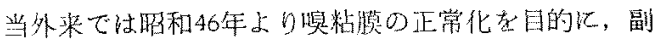

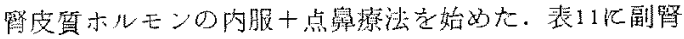




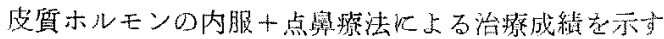
治瘾，蛏快，含めての治療刘果のあったものは72.9\%て

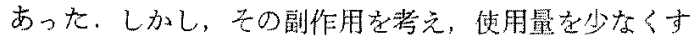

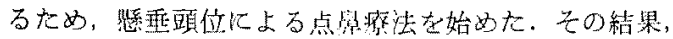
内服十点嶨と, 点罟療法のみの治療法の間には, はと儿

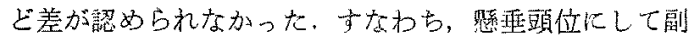
腎皮啠ホルモン点舅し，5分間艺のままの姿勢を保て ば，副婜皮筫ホルモンを内服するのとほほ间様の効果が

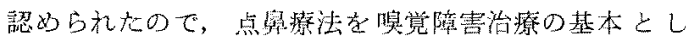
t.

表11 副留皮澌ホルモン内服十点鼠潦法に よる治療成縝

\begin{tabular}{lll}
\hline 治 & 瘾 & 123 例 $(30.8 \%)$ \\
杯 & 快 & 169 例 $(42.1 \%)$ \\
無 & 効 & 109 例 $(27.2 \%)$
\end{tabular}

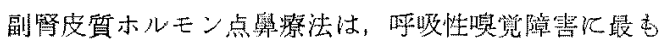

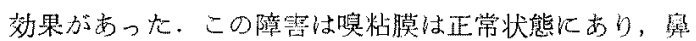
内気流の異常儿よって和こるものであるから，鼠腔内の

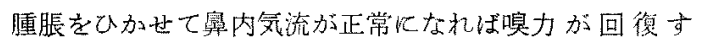
る、面管取縮剂を先行して便用した副留皮質ホルモン点

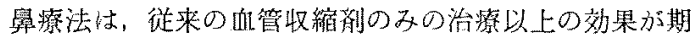
待できた。

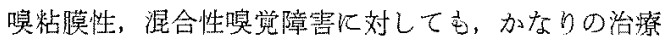
効果が市った。このうち針状硬性鏡検查で，分倏型，腫

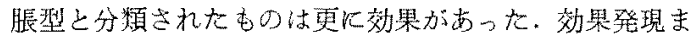
ての時間委短く早い屯のは点森使用当日，多くは3〜4 日目頃住回復るることができた。しかし，この時点て

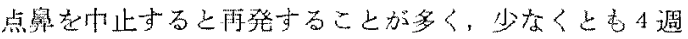

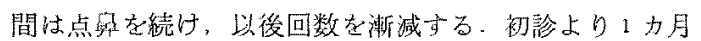

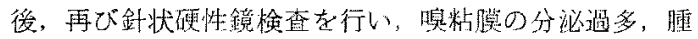
脹がなくなっていることも確認した。

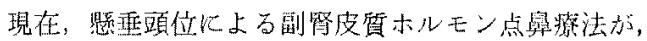
なぜ鮕筧障害飞効果があるかは不明である。高橋らは，

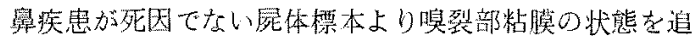

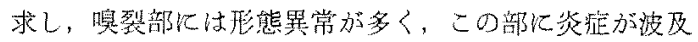

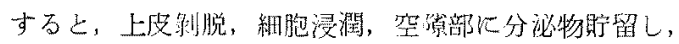
それが器質化し，また，上皮が重居瀜平化するですう

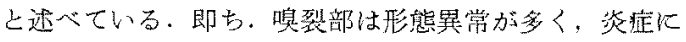

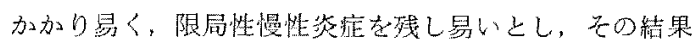

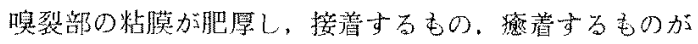

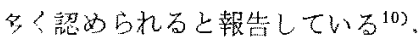

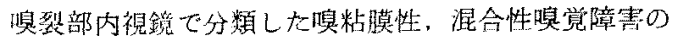

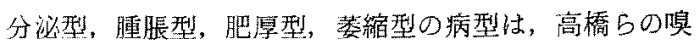
裂炎から嗅裂部分接着ないし癒着の状態になる道程の病 態所見であると考られる。

しかし，井澤は，鮕裂部の病態と鮕賞障書を臨床的に

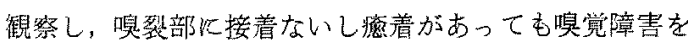
自覚しないものがあると述へている11

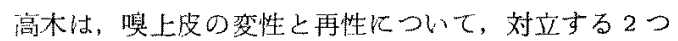
の意見があると報告している，暞上皮は感営ニューロン を身体の外表面に，きわめて近い位置に持ち，発達次元 の非常に低い組織であることを考えれば，ある末分化二 ュ一ロンが条件によっては，有系核分裂を㨟こして增加 し発達して新しいニューロンとなっても少しも警くに傎 しないと思われるといっている122。

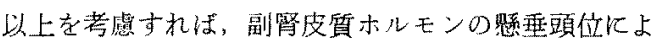
る点翼療法が, 分泌型, 舟脹型には多くの効果を示し, 肥厚型，萎縮型には余り反応しないことは理解できる。 副督皮梊ホルモンの多くの薬理作用のうち，強い消炎作 用，莯アレルギ一作用，細胞機能修復作用，恒常性維持

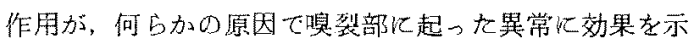
しているものと考光。，中枢性橖覚障害については，今 後の研究をまちたい。

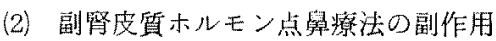

一般に副督皮質ホルモンは臨床的化多くの㹝果をむた らしているが，その副作用も多彩である。昭和大学病院

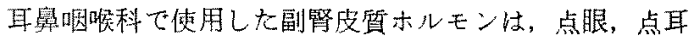
液しして発売されている0.1\%デキサメサゾンか，ベタ メサゾンで, 1 回量は各㑬 $1 \sim 2$ 滴で, 1 日朝, 晚 2 回 行う. $5 \mathrm{ml}$ 週間の割で投与した。点鼻した全量が

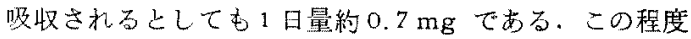
の量では副婜皮犋ホルもンの副作用のうち重篤なものは

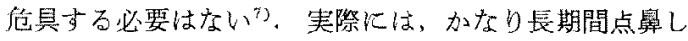
た患者で時に肥渾を訴えるものがいる程度である，その ため副婜皮留機能について検討を加えた。

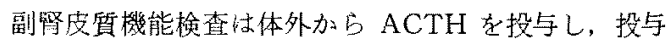
前と投与後の血中 11-OHCS を測定し比较する力法を用 いた。併来は天然 ACTH を使用していたが，最近開発 された命成 $\mathrm{ACTH}$ (一般名，酢酸ギラクチド，腹品名， アククルモン使用火よる迅速副繁皮質機能検查は，危 険性が少なく，再現性があり，被検者入口精神的，肉体 的負担を与えず，特に外来で短時閶に行充る検查法であ る.

この喽查の結果，新㭧群に把いては，30例中29例が正。 
常反応を示し，検查法の信䫅性が認められた，点嶨群で は副腎皮質木ルモン点鼻闆始捘，4 力月までのものは， 正常反忘走していた。 その後, 5 力月，6力月飞 1 部 機能低下と判定されたものがいるが，これに反して29力

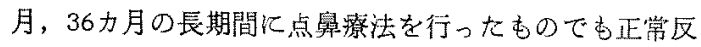
応を示しているあのもある。これは副紫皮質ホルモンの 感受性以個人差があるためか, 点䦩量が少ないので， あ る程度の期間使用していると副肾皮質に“慣れ”が生じ てくるためか，点臭を続けながら検查を行った絬果か， 今後検討を必要とする。

一般次内服では1日量 $0.5 \mathrm{mg}$ 以下の投与では数年間 の治療ののち毛副珡皮質機能検查は正常反念を示すとい われている ${ }^{13) 14}$. 昭和大学病院耳畕咽喉科で使用してい る点舅量は，全量が吸仪されたとしても1日量約 $0.7 \mathrm{mg}$ であるので，その量は微量で問題にするにあたらない， しかし，患者によっては，多ければ多い程，効果がある ものと考える人もあり，また，舆期閽使用の必要性のあ

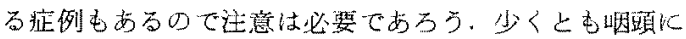
流下する点鼻蔡は可及的に昍出する上う注意する必要が ある。

副腎皮質ホルモン療法に上る副腎皮質機能低下は決し て不可逆的なものでなく, 中止すれば必ず正常な機能に 回復する $\left.{ }^{15}\right)^{16}$ ).

\section{II 結 論}

唤覚障害治療の現状は，一般的な鼻疾患の治療にビタ

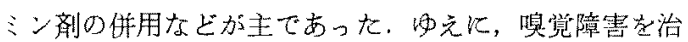
すことは，ほとんど不可能で，嗅覚障害は治し難い疾患 と考光られていた。

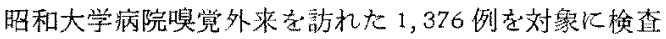

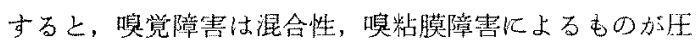
倒的に多く $96 \%$ に達し，呼吸性，中枢性障害によるもの は，ごく少数であった。

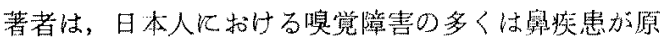
因で㟟起された㖵粘膜そのものの病的变化によるもの上 考光，㖵粘膜病变そのむのの治潦に着目し，本研究老行 った。

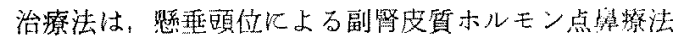

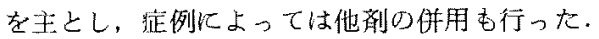

（1）成積性，呼吸性嗅営障害では87.5\%，嗅粘膜性嗅 党㖏害では $68.6 \%$ ，湿合性嗅觉障害では $75.7 \%$ \%か沿㴔 ないし軽快し，中枢性嗅筧障害の回復は認力口れなか力。 た。ことに检状硬性鏡検查にて分泌型，腫脹型には著効 があり，肥厚型，菱縮型には余り反忘しなかった。
（2）鄙賞障害の治潦に上って，現在，副等皮質木ルモ ンに勝る他剂は，発見できなかった。また，副㹂皮質木

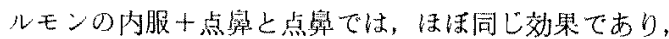
副作用の面を考慮すると，点翼潦法が最も良いと断定し た.

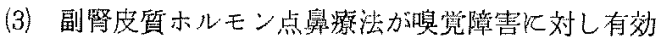
である琵由は，副督皮質ホルモンの強い消炎作用，抗了 レルギー作用, 紬胞㙨能修復作用, 恒常性維持作用が, 咱裂部の異常飞効果を示したものと考える.

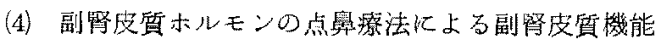
そついては, Rapid ACTH test を行い，1 週間に0.1 $\%$ デキナメサゾンまたは， ベタメサゾン水溶液を $5 \mathrm{~m} l$ の割で使用すれば，16週まてのものには，その变化が㒛 められなかった。

（5）中枢性㕷覚障害之，嗅粘膜性，混合性嗅喾障害の 一部炕，副腎皮質ホルモンに反応しないものがあった がこれについては，今後の研究をまちたい，

以上より昭和大学病院嗅賞外来倸来院した嗅覚障害者

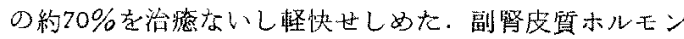

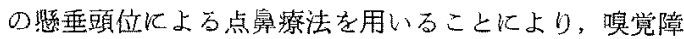
害は治り難い疾患ではなく，治し易い疾患であると考兄 る.

\section{文献}

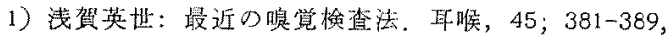
1973.

2）线賀英世：第79回日耳䊌総会研修会テキス卜「嗅賞 㛟查法」。1975.

3）梅田良三，他：ルーチンテストとしての唤覚検査法 飞ついて。取䀧，42；643-647，1970.

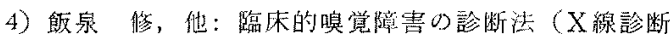

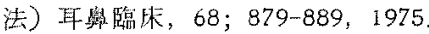

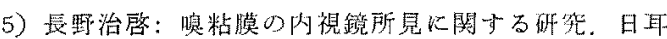
率, $80 ; 241-248,1977$.

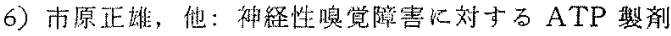
の使用経驙。耳喉，35；871-873，1963.

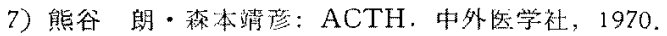

8）井林 推, 他: Rapid ACTH test. medicina, 12; $648650,1975$.

9) 竹部和夫: [Gly']-ACTH (1-18)-octadecapeptde

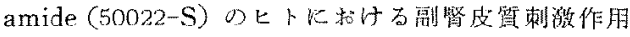
について，䥻新医学，25；1971-1977，1970.

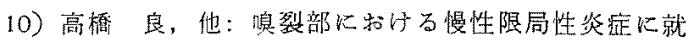


いて。目帠，61；231，1958。

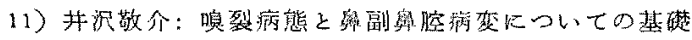

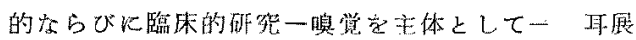
$16 ; 133-181,1973$.

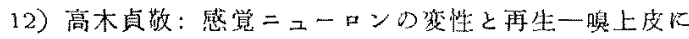
関する何婪一 神経進步，13；152-163，1969.

13) Danowski, T.S, et al.:. Probabilities of PituitaryAdrenal Reaponsiveness After Steroid Therapy. Annals Int. Med., 61; 11-26, 1964.

14) Tredwell. B.L.J, et al.: Pituitary-Adrenal Function During Corticosteroid Therapy. Lancet., $1 ; 355-358$, Feb. 16, 1963.

15) Meakin, $J W$, et al.: Pituitary-Adrenal Function Following Long-Term Steroid Therapy. Amer. J. Med., 29; 459-464, 1960.
16) GraBer, A.L., at al.: Natural History of Pituitary-Adrenal Recovery Following Long-Term Supression with Corticosteroids. J. clin. End, $25 ; 11-16,1965$.

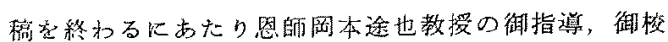

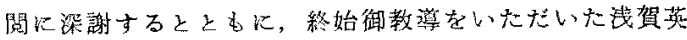
世助教授飞感謝致しす。また，嗅覚㴬の諸先生に謝意 を裴します。

本馀交の要旨は，第77回日耳黁総会学術講演会，第14

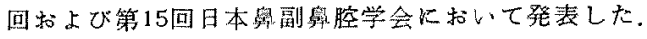

（原稿受村 昭和52.10.6日)

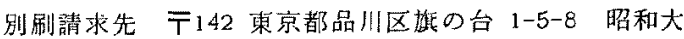
学医学部耳鼻咽㬋科学教室 福島激子 